\title{
PENGARUH METODE BERMAIN PERAN TERHADAP HASIL BELAJAR SISWA DALAM PEMBELAJARAN PKN DI SEKOLAH DASAR
}

\author{
Nera Sarmila ${ }^{1)}$, Reinita ${ }^{2),}$ Mayarnimar $^{3)}$ \\ ${ }^{1)}$ Mahasiswa, Universitas Negeri Padang \\ ${ }^{2}$ Pembimbing 1, Universitas Negeri Padang \\ ${ }^{3)}$ Pembimbing 2, Universitas Negeri Padang \\ ${ }^{1)}$ nerasarmila96@gmail.com, ${ }^{2)}$ reinita_reinita@yahoo.com ${ }^{3)}$ mayar.nimar@yahoo.com,
}

\begin{abstract}
Abstrak
Penelitian ini bertujuan untuk mengetahui pengaruh penggunaan metode bermain peran terhadap hasil belajar siswa dalam pembelajaran PKn di kelas V SDN 17 Batu Gadang Agam. Penelitian ini merupakan penelitian kuantitatif dengan jenis penelitian eksperimen dan desain penelitian Quasi Experimental Type Nonequivalent Control Group Design. Pengambilan data sampel dilakukan dengan menggunakan teknik total sampling dengan jumlah sampel 56 siswa. Instrumen yang digunakan berupa tes objektif dengan bentuk pilihan ganda. Berdasarkan penelitian yang telah dilakukan, dari hasil uji-t dengan taraf signifikansi 5\% diperoleh $\mathrm{t}_{\text {hitung }} 3,2480>\mathrm{T}_{\text {tabel }} 2,00488$. Dengan demikian terdapat pengaruh yang signifikan dalam penggunaan metode bermain peran terhadap hasil belajar siswa dalam pembelajaran PKn di Kelas V SDN 17 Batu Gadang Agam.
\end{abstract}

Kata Kunci: Pkn, Metode Bermain Peran, Hasil Belajar

\section{THE EFFECT OF ROLE-PLAYING ON THE SRUDENTS' CIVICS EDUCATION LEARNING OUTCOME IN ELEMENTARY SCHOOL}

\begin{abstract}
This study aims to determine the effect of the role-playing method on the students' civics education learning outcome in Grade V of Elementary School Number 17 Batu Gadang, Agam. This is quantitative research with a quasi-experimental type of nonequivalent control group design. Data collection was performed using total sampling technique with the number of samples amounted to 56 students. The research instrument was in the form of a multiple-choice item test. Based on the result of the t-test with the significance $5 \%$, it was found that $\mathrm{t}_{\text {test }} 3.2480>\mathrm{t}_{\text {tabel }} 2.00488$. Thus, it is concluded that the use of role-playing method has a significant effect on the students civics education learning outcome in Grade V of Elementary School Number 17 Batu Gadang, Agam.
\end{abstract}

Keywords: PKn, Role Playing Method, Learning Outcome 


\section{PENDAHULUAN}

Metode pembelajaran didefinisikan sebagai cara yang digunakan guru dalam menjalankan fungsinya dan merupakan alat untuk mencapai tujuan pembelajaran. Metode pembelajaran lebih bersifat prosedural, yaitu berisi tahapan tertentu.

Penggunaan berbagai metode harus disesuaikan dengan karakteristik tujuan pembelajaran, karakter atau kualifikasi butiran materi pembelajaran, situasi dan lingkungan belajar siswa, tingkat perkembangan dan kemampuan belajar siswa.

Berdasarkan observasi yang peneliti lakukan pada tanggal 12 Juli 2018 di kelas V SDN 17 Batu Gadang Agam. Permasalahan yang terlihat dalam proses pembelajaran yaitu antara lain: (1) proses pembelajaran di kelas $\mathrm{V}$ masih berpusat pada guru, (2) suasana kelas cenderung menoton dan membosankan, (3) siswa tidak pernah diajak dalam bermain peran, (4) siswa tidak belajar mengekspresikan penghayatan mengenal suatu masalah di depan umum, (5) dalam pembelajaran tidak mengembangkan nilai dan sikap siswa.

Permasalahan tersebut mengakibatkan hasil pembelajaran tidak mencapai standar yang telah ditentukan dan proses pembelajaran tidak berpusat kepada siswa serta metode yang digunakan tidak merangsang siswa untuk aktif karena guru selalu mendominasi pembelajaran dengan ceramah dan memberikan tugas saja. Sehingga hasil belajar siswa tidak maksimal karena hanya memuat aspek kognitif saja, sedangkan afektif dan psikomotor kurang diperhatikan guru. Sedangkan menurut Reinita (2012:1) "dalam pembelajaran $\mathrm{PKn}$, materi pelajarannya meliputi multi ranah yang terdiri dari ranah kognitif, afektif, dan psikomotor yang kesemuanya perlu dibelajarkan dan dikuasi oleh siswa setelah pembelajaran selesai dilaksanakan".

Untuk mencapai hasil pembelajaran Pendidikan Kewarganegaraan yang sesuai dengan harapan, maka diharapkan metode pembelajaran yang digunakan harus terpusat pada siswa. Menurut peneliti salah satu metode pembelajaran yang dianggap cocok diterapkan untuk mencapai hasil pembelajaran yang diinginkan yaitu dengan menggunakan metode bermain peran, agar pembelajaran menjadi aktif, bervariasi dan menyenangkan sehingga siswa menjadi lebih semangat dan penuh antusias mengikuti pembelajaran Pendidikan Kewarganegaraan. 
Untuk mengatasi kesenjangan tersebut dilakukanlah tindakan yang mampu meningkatkan hasil

belajar siswa yaitu dengan menggunakan metode bermain peran.

Menurut Hamdayama (2014:189) "Metode bermain peran merupakan suatu cara penguasaan bahan-bahan pelajaran melalui pengembangan imajinasi dan penghayatan siswa". Pengembangan imajinasi dan penghayatan dilakukan siswa dengan memerankannya sebagai tokoh hidup atau benda mati.

Metode bermain peran atau role playing dilakukan dengan cara mengarahkan siswa untuk menirukan aktivitas di luar atau mendramatisasikan situasi, ide, maupun karakter khusus. Guru menyusun dan memfasilitasi permainan peran kemudian ditindak lanjuti dengan diskusi. Selama permainan berlangsung, siswa lain yang tidak turut bermain diberi tugas mengamati, merangkum pesan yang tersembunyi dan mengevaluasi permainan peran.

Berdasarkan latar belakang di atas, maka permasalahan yang dapat diidentifikasi sebagai berikut: (1) Proses pembelajaran di kelas V SDN 17 Batu Gadang Agam masih berpusat pada guru dan suasana kelas cenderung menoton,
(2) Siswa dalam belajar masih bersifat pasif dan cenderung membosankan. (3) Guru tidak pernah menggunakan metode bermain peran dalam proses pembelajaran. (4) Guru selalu mendominasi menggunakan pembelajaran dengan metode ceramah dan penugasan. (5) Hasil belajar PKn siswa kelas V SDN 17 Batu Gadang Agam masih ada yang dibawah Kriteria Ketuntasan Minimal (KKM) yang telah ditetapkan yaitu 75 .

Terkait dengan beberapa masalah tersebut diatas karena keterbatasan waktu penelitian serta agar penelitian lebih terarah, maka perlu dibuat pembatasan permasalahan yang akan diteliti, yaitu sebagai berikut: (1) Metode pembelajaran dibatasi pada metode bermain peran pada kelompok eksperimen dan model pembelajaran konvensial kelompok kontrol. Subyek penelitian dibatasi pada siswa kelas VA SDN 17 Batu Gadang Agam sebagai kelas kontrol dan kelas VB SDN 17 Batu Gadang Agam sebagai kelas eksperimen.

\section{METODE PENELITIAN}

Penelitian ini menggunakan penelitian kuantitatif. Penelitian kuantitatif digunakan apabila peneliti ingin mengetahui pengaruh atau 
traeatmen tertentu terhadap suatu permasalahan (Sugiyono, 2012: 34).

Jenis penelitian yang dipakai adalah penelitian eksperimen. Menurut

Sugiyono (2012:107), penelitian eksperimen dapat diartikan sebagai metode penelitian yang digunakan untuk mencari pengaruh perlakuan tertentu terhadap yang lain dalam kondisi yang terkendalikan.

Penelitian ini menggunakan nonequivalent control group design yang mana desain ini hampir sama dengan pretest-posttest control group design, hanya pada desain ini kelompok eksperimen maupun kelompok kontrol tidak dipilih secara random. Penggunaan metode tersebut dalam penelitian ini dipandang tepat karena penelitian ini bertujuan untuk memperoleh informasi tentang pengaruh penggunaan metode bermain peran terhadap hasil belajar siswa dalam pembelajaran PKn di kelas V SDN 17 Batu Gadang Agam. Alasan lain peneliti memilih metode ini dikarenakan pada penelitian ini penentuan sampel tidak secara random sehingga dapat mempermudah pelaksanaan penelitian di sekolah dasar.

Dalam penelitian ini melibatkan dua kelompok yaitu kelompok eksperimen dan kelompok kontrol. Kegiatan eksperimen pada penelitian ini dilakukan pada kelompok siswa kelas V, yang terdiri dari kelas kontrol dan kelas eksperimen. Kelas eksperimen yaitu kelompok siswa yang mendapat metode bermain peran. Kelas kontrol yaitu kelompok siswa yang tidak mendapatkan metode bermain peran atau yang menggunakan metode ceramah. Kedua kelas mempunyai kemampuan yang setara atau homogen.

Tabel.Desain Penelitian

\begin{tabular}{cccc}
\hline Kelompok & $\begin{array}{c}\text { Pre- } \\
\text { test }\end{array}$ & Perlakuan & Post- \\
& & & test \\
Eksperimen & $\mathrm{O}_{1}$ & $\mathrm{X}$ & $\mathrm{O}_{2}$ \\
Kontrol & $\mathrm{O}_{3}$ & - & $\mathrm{O}_{4}$ \\
& & & \\
\hline
\end{tabular}

(Sugiyono, 2012: 116)

Keterangan :

$\mathrm{X}$ : Penggunaan metode bermain peran

$\mathrm{O}_{1}$ : Pre-test (tes berupa soal sebelum pembelajaran dengan menggunakan metode bermain peran)

$\mathrm{O}_{2}$ : Post-test (tes berupa soal sesudah pembelajaran dengan menggunakan metode bermain peran)

$\mathrm{O}_{3}$ : Pre-test (tes berupa soal sebelum pembelajaran dengan menggunakan metode ceramah)

$\mathrm{O}_{4}$ : Post-test (tes berupa soal sesudah pembelajaran dengan menggunakan metode ceramah) 
Populasi penelitian ini adalah seluruh siswa Kelas V SDN 17 Batu Gadang Agam yang terdaftar pada tahun ajaran 2018/2019. Sampel dalam penelitian ini adalah seluruh siswa kelas V SDN 17 Batu Gadang Agam. Jumlah keseluruhan siswa kelas $\mathrm{V}$ yaitu 56 siswa, dengan rincian kelas $\mathrm{V} A$ berjumlah 28 siswa dan kelas V B berjumlah 28 siswa.

Teknik sampling yang digunakan dalam penelitian ini adalah teknik total sampling. Alasan peneliti menggunakan teknik total sampling jumlah populasi pada penelitian ini hanya berjumlah 52 orang. Menurut Suharsimi (2006:134) "Apabila kurang dari 100 lebih baik diambil semua hingga penelitiannya merupakan penelitian populasi”.

Instrumen yang akan digunakan dalam penelitian berupa tes. Menurut Uno dan Koni (2012:111) “Tes merupakan seperangkat rangsangan (stimuli) yang diberikan kepada seseorang dengan maksud untuk mendapatkan jawaban-jawaban yang menjadi dasar bagi penetapan skor angka”. Dalam penelitian ini uji instrument dilakukan pada siswa diluar kelas eksperiman dan kelas Kontrol. Setelah melakukan uji coba instrument, langkah selanjutnya adalah mengolah data hasil uji coba dengan mencari daya pembeda, taraf kesukaran, validitas dan reliabelitas. 1) Instrument yang valid berarti alat ukur yang digunakan untuk mendapatkan data ( mengukur) itu valid. Valid berarti intrumen tersebut dapat digunakan untuk mengukur apa yang seharusnya diukur. Dari hasil perhitungan dengan menggunakan rumus menggunakan rumus $\Upsilon_{p b i}$ yang disebut dengan korelasi biserial, terdapat 16 soal dengan kriteria sangat rendah(SR), 5 Rendah(R), 16 Cukup(C), kriteria tInggi ada 2 butir soal dan 1 butir soal sangat tinggi (ST). Jumlah soal yang terpakai 25 soal. 2) Daya beda. Derajat daya pembeda (DP) suatu butir soal dinyatakan dengan indeks diskriminan yang bernilai -1,00 sampai dengan 1,00. Apabila indeks diskriminan makin mendekati nilai 1,00 ini berarti daya pembeda soal semakin baik, begitu juga sebaliknya, jika indeks diskriminan suatu soal mendekati nilai 0,00 maka daya pembeda soal tersebut sangat jelek. Indeks diskriminasi butir soal bernilai negatif (antara 0,00 sampai $-1,00)$ ini berarti kelompok siswa kurang mampu banyak yang menjawab benar, sebaliknya banyak siswa yang pintar menjawab salah. Sedangkan jika suatu butir soal memiliki indeks deskriminasi 0,00 berarti bahwa soal tersebut tidak memiliki daya pembeda, artinya baik 


\section{e- Jurnal Inovasi Pembelajaran SD}

Volume 1, Tahun 2018

siswa pandai maupun yang kurang mampu menjawab benar soal tersebut. Dari hasil perhitungan terdapat 1 soal baik sekali, 3 soal yang baik, 9 soal yang cukup, dan 27 soal yang jelek. 3) Indeks kesukaran. Tingkat kesukaran seluruh butir soal dinyatakan dengan bilangan yang disebut dengan indeks kesukaran (difficulty indeks ) indeks kesukaran berkisar antara nilai 0,00 sampai dengan 1,00. Soal dengan indeks kesukaran 0,00 berarti butir soal tersebut terlalu sukar, sebaliknya indeks kesukaran soal mendekati 1,00 berarti soal tersebut terlalu mudah. Dari hasil perhitungan terdapat 2 butir soal yang termasuk dalam klasifikasi sukar, 10 butir soal yang termasuk dalam klasifikasi sedang, 28 butir soal yang termasuk dalam klasifikasi mudah, 4) Reliabilitas instrument dibutuhkan untuk mengetahui sejauh mana ketepatan butir-butir soal tes sehingga dapat digunakan sebagai instrument penelitian. Berdasarkan hasil analisis uji reliabilitas diperoleh $\mathrm{r} 11=0,99$. Dari perhitungan ini dapat ditentukan bahwa derajat reliabilitas instrument sangat tinggi Data yang diperoleh dalam penelitian dianalisis dengan menggunakan analisis statistik parametrik. Sebelum dilakukan uji hipotesis terlebih dahulu dilakukan uji prasyarat analisis yaitu menganalisis uji normalitas dan menganalisis uji homogenitas data sebagai persyaratan penggunaan statistik parametrik. Hipotesis penelitian diuji dengan menggunakan rumus uji-t.

$\begin{array}{lllr}\text { Data yang } & \text { diperoleh } & \text { dalam } \\ \text { penelitian akan } & \text { dianalisis } & \text { dengan } \\ \text { menggunakan } & \text { analisis } & \text { statistik }\end{array}$
parametrik. Sebelum dilakukan uji hipotesis terlebih dahulu dilakukan uji prasyarat analisis yaitu menganalisis uji normalitas dan menganalisis uji homogenitas data sebagai persyaratan penggunaan statistik parametrik. Hipotesis penelitian diuji dengan menggunakan rumus uji-t.

Kriteria pengujian $\mathrm{H}_{0}$ ditolak jika $\mathrm{t}_{\text {hitung }}>\mathrm{t}_{\text {tabel }}$, dengan taraf signifikansi $5 \%$.

\section{HASIL DAN PEMBAHASAN}

\section{A. Deskripsi Data}

1. Deskripsi Data Pretest Kelas Eksperimen dan Kelas Kontrol

Sebelum penelitian dilakukan, terlebih dahulu kedua kelompok baik itu kelompok eksperimen maupun kelompok kontrol di beri tes awal (pretest) dan pada akhir penelitian diberi tes akhir (posttest). Pretest pada kelas VA dan VB dilaksanakan pada hari Senin, 27 Agustus 2018. 
Data yang diperoleh dari pretest kedua kelas tersebut diolah dengan manual dengan bantuan microsoft office excel. Data yang terkumpul disajikan dalam tabel berikut:

Tabel 4.1 Data Hasil Pretest Kelas Eksperimen dan Kelas Kontrol

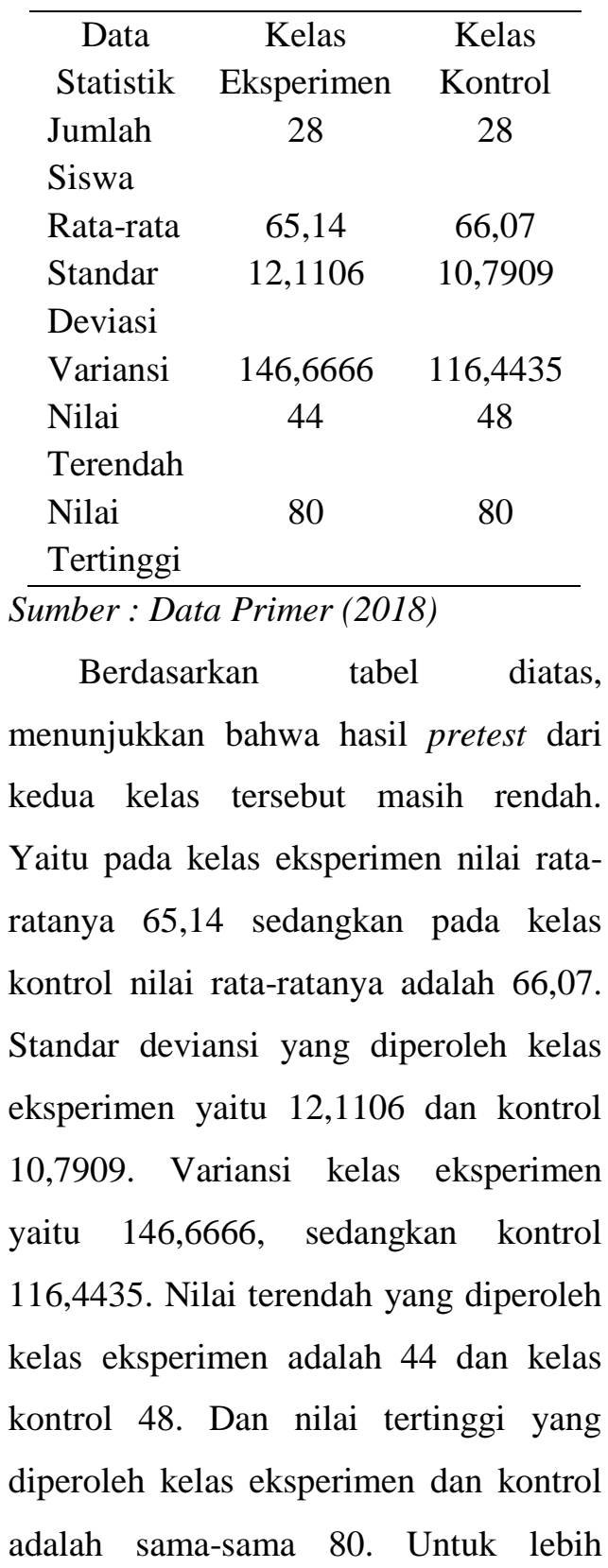

jelasnya melihat nilai pretest kelas eksperimen dan kelas kontrol bisa dilihat dilampiran 9 hal 127.

Berikut ini adalah distribusi frekuensi perolehan nilai pretest kelas eksperimen dan kontrol.

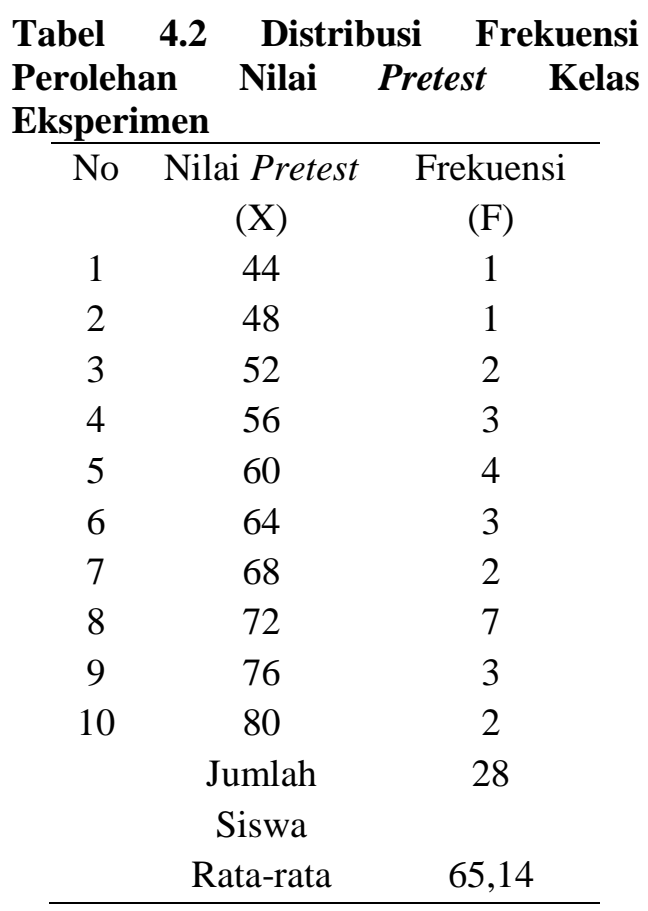

Berdasarkan tabel di atas, dapat diketahui bahwa nilai rata-rata kelas eksperimen masih rendah yaitu 65,14. Dengan rincian, nilai yang paling banyak didapatkan oleh siswa adalah nilai 72 yaitu sebanyak 7 orang. Selanjutnya nilai 60 sebanyak 4 orang, nilai 56,64,76 sebanyak 3 orang. 52, 68 dan 80 sama-sama sebanyak 2 orang, dan 44 dan 48 sebanyak 1 orang.

Tabel 4.3 Distribusi Frekuensi Perolehan Nilai Pretest Kelas Kontrol \begin{tabular}{lll}
\hline No & Nilai Pretest & Frekuensi \\
\hline
\end{tabular} 


\begin{tabular}{ccc}
\hline & $(\mathrm{X})$ & $(\mathrm{F})$ \\
1 & 48 & 2 \\
2 & 52 & 1 \\
3 & 56 & 1 \\
4 & 60 & 6 \\
5 & 64 & 4 \\
6 & 68 & 3 \\
7 & 72 & 4 \\
8 & 76 & 6 \\
9 & 80 & 1 \\
& Jumlah & 28 \\
& Siswa & \\
& Rata-rata & 66,07 \\
\hline
\end{tabular}

Berdasarkan tabel distribusi frekuensi di atas, dapat diketahui bahwa nilai kelas kontrol masih rendah yaitu sebesar 66,07. Dengan rincian, nilai 60 dan 76 adalah nilai yang paling banyak didapatkan oleh siswa yaitu sebanyak 6 orang. Selanjutnya nilai 64 dan 72 sama-sama sebanyak 4 orang, nilai 68 sebanyak 3 orang, nilai 48 sebanyak 2 orang. Dan nilai 52, 58, 60 sama-sama 1 orang.

Distribusi nilai pretest kelas eksperimen dan kelas kontrol dapat disajikan pada diagram dibawah ini.

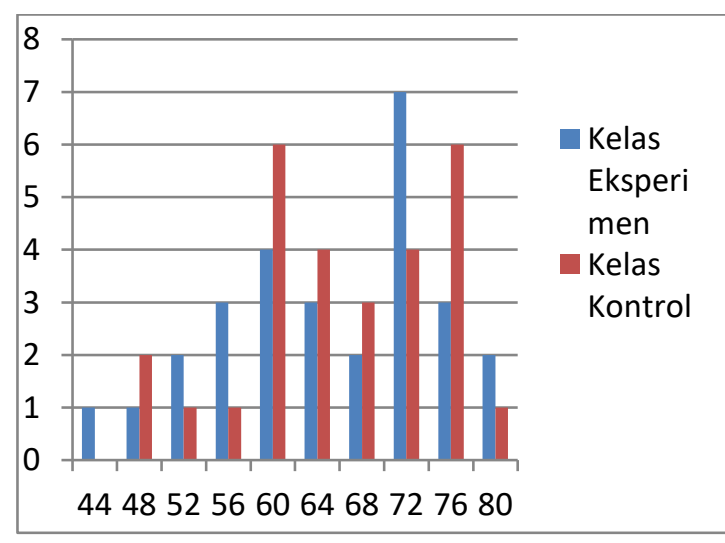

Gambar 4.1 Diagram Batang Distribusi Frekuensi Nilai Pretest Kelas Eksperimen dan Kelas Kontrol

Perbandingan nilai rata-rata pretest kelas eksperimen dan kontrol dapat disajikan kedalam grafik dibawah ini:

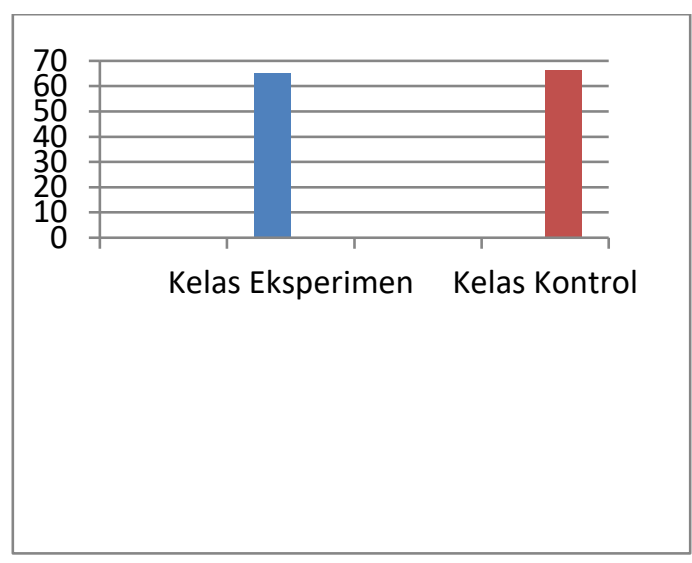

Gambar 4.2 Diagram Batang Perbandingan Nilai Rata-rata Pretest

Kelas Eksperimen dan control

Diagram batang di atas dapat dilihat nilai rata-rata kelas eksperimen lebih rendah daripada kelas kontrol, hal ini dilihat dari nilai rata-rata pretest kelas eksperimen sebesar 65,14 dan nilai ratarata pretest kelas kontrol sebesar 66,07. Sehingga dapat disimpulkan bahwa terdapat

perbedaan nilai rata-rata pretest kelas eksperimen dan kelas kontrol.

\section{Deskripsi Data Posttest Kelompok \\ Eksperimen dan Kelompok \\ Kontrol}


Pemberian posttest kepada kelompok eksperimen dimaksudkan untuk melihat hasil pencapaian pembelajaran PKn materi contoh-contoh perilaku dalam menjaga keutuhan Negara Kesatuan Republik Indonesia dengan menggunakan metode bermain peran. Sedangkan posttest kelompok kontrol dimaksudkan untuk melihat hasil pencapaian pembelajaran $\mathrm{PKn}$ materi contoh-contoh perilaku dalam menjaga keutuhan Negara Kesatuan Republik Indonesia tanpa menggunakan metode bermain peran. Subjek kedua kelompok ini masing-masing berjumlah 28 orang siswa.

Data yang diperoleh dari posttest kedua kelompok tersebut diolah manual dengan bantuan microsoft office excel. Data yang terkumpul disajikan dalam tabel berikut:

Tabel 4.4 Data Hasil Postest Kelas Eksperimen dan Kelas Kontrol

\begin{tabular}{lcc}
\hline \multicolumn{1}{c}{ Data } & Kelas & Kelas \\
Statistik & Eksperimen & Kontrol \\
Jumlah & 28 & 28 \\
Siswa & & \\
Rata-rata & 79,85 & 71,71 \\
Standar & 7,4833 & 10,9544 \\
Deviasi & & \\
Variansi & 55,9997 & 119,9988 \\
Nilai & 68 & 52 \\
Terendah & & \\
Nilai & 88 & 84 \\
Tertinggi & \multicolumn{2}{l}{} \\
\hline (Sumber : Data Primer (2018)
\end{tabular}

Berdasarkan tabel diatas, dapat dilihat dari segi nilai rata-rata siswa kelas eksperimen lebih tinggi daripada kelas kontrol yang tidak menggunakan metode bermain peran yaitu pada kelas eksperimen nilai rata-ratanya adalah 79,85 sedangkan nilai rata-rata posttest pada kelas kontrol hanya 71,71 . Standar deviansi yang diperoleh kelas eksperimen yaitu 7,4833 dan kelas kontrol 10,9544. Sedangkan variansi yang diperoleh kelas eksperimen yaitu 55,9997, sedangkan kelas kontrol 119,9988 . Nilai terendah yang diperoleh kelas eksperimen adalah 48 dan kelas kontrol 44. Dan nilai tertinggi yang diperoleh kelas eksperimen adalah 88 dan kelas kontrol adalah 84 .

Tabel 4.5 Distribusi Frekuensi Perolehan Nilai Posttest Kelompok Eksperimen

\begin{tabular}{|c|c|c|}
\hline No & Nilai Posttest & $\begin{array}{l}\text { Frekuensi } \\
\text { (Fi) }\end{array}$ \\
\hline 1 & 68 & 1 \\
\hline 2 & 72 & 3 \\
\hline 3 & 76 & 6 \\
\hline 4 & 80 & 8 \\
\hline 5 & 84 & 6 \\
\hline \multirow[t]{3}{*}{6} & 88 & 4 \\
\hline & Jumlah siswa & 28 \\
\hline & Rata-rata & 79,85 \\
\hline \multicolumn{3}{|c|}{$\begin{array}{l}\text { Berdasarkan tabel di atas, dapat } \\
\text { etahui bahwa pada hasil rata-rata } \\
\text { ttest kelas eksperimen adalah sebesar }\end{array}$} \\
\hline \multicolumn{3}{|c|}{$\begin{array}{l}79,85 \text {. Dengan rincian, nilai yang paling } \\
\text { banyak didapatkan oleh siswa adalah }\end{array}$} \\
\hline
\end{tabular}


nilai 80 yaitu sebanyak 8 orang. Selanjutnya nilai 76 dan 84 sebanyak 6 orang, nilai 88 sebanyak 4 orang, nilai 72 sebanyak 3 orang. Dan nilai 68 sebanyak 1 orang.

\section{Tabel 4.6 Distribusi Frekuensi}

Perolehan Nilai Posttest Kelompok

\section{Kontrol.}

\begin{tabular}{ccc}
\hline No & Nilai Posttest & Frekuensi (F) \\
1 & 52 & 1 \\
2 & 56 & 1 \\
3 & 60 & 2 \\
4 & 64 & 3 \\
5 & 68 & 3 \\
6 & 72 & 4 \\
7 & 76 & 7 \\
8 & 80 & 6 \\
9 & 84 & 1 \\
& Jumlah Siswa & 28 \\
& Rata-rata & 71,71 \\
\end{tabular}

Berdasarkan tabel di atas, dapat diketahui bahwa nilai posttest kelas kontrol masih rendah yaitu 71,71. Dengan rincian, nilai yang paling banyak didapatkan oleh siswa adalah nilai 76 yaitu sebanyak 7 orang. Selanjutnya nilai 80 sebanyak 6 orang, nilai 72 sebanyak 4 orang, nilai 64 dan 68 sebanyak 3 orang, nilai 60 sebanyak 2 orang. Dan nilai 52, 56, dan 84 sebanyak 1 orang.

Distribusi nilai posttest kelas eksperimen dan kelas kontrol dapat disajikan pada diagram dibawah ini.

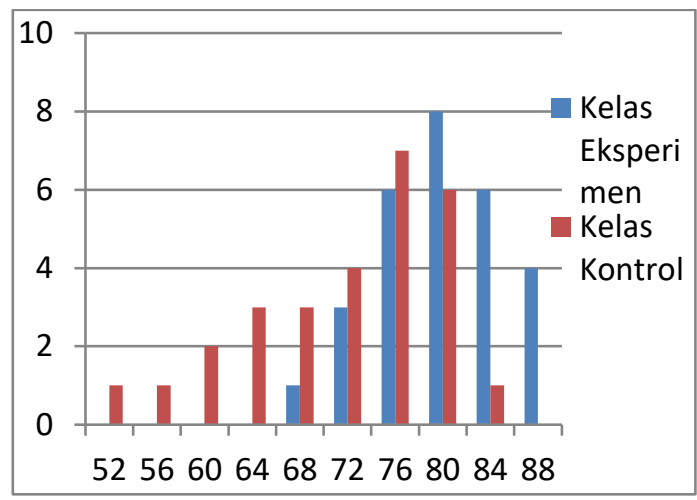

Gambar 4.3 Diagram Batang Distribusi Frekuensi Nilai Posttest Kelas Eksperimen dan Kelas Kontrol

Perbandingan nilai rata-rata posttest kelas eksperimen dan kontrol dapat disajikan kedalam gambar dibawah ini.

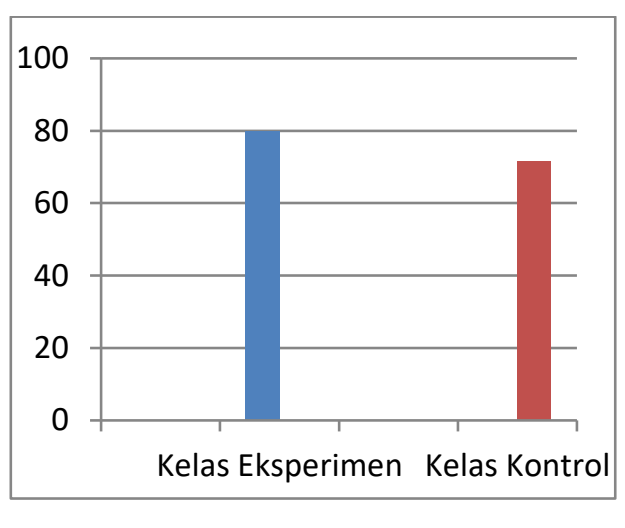

Gambar $4.4 \quad$ Diagram Batang Perbandingan Nilai Posttest Kelas Eksperimen dan control

Diagram di atas dapat dilihat bahwa terdapat perbedaan nilai rata-rata posttest kelas eksperimen dan kelas kontrol. Nilai rata-rata posttest kelas eksperimen adalah 79,85. Sedangkan nilai rata-rata posttest kelas kontrol sebesar 71,71 . Selisih nilai rata-rata

kedua kelas adalah 8,14 . Selisih ini menjelaskan bahwa kedua kelas 
memiliki perbedaan hasil belajar setelah menerima pembelajaran dengan metode yang berbeda.

\section{Perbandingan Data Pretest dan Posttest Kelompok Eksperimen dan Kelompok Kontrol}

Perbandingan data pretest-posstest kelompok eksperimen dan kelompok kontrol dapat dilihat tabel dibawah ini:

Tabel 4.7 Perbandingan Data PretestPosttest Kelompok Eksperimen dan Kelompok Kontrol

\begin{tabular}{|c|c|c|c|}
\hline $\mathbf{N}$ & Kelompok & \multicolumn{2}{|c|}{ Nilai Rata-rata } \\
\hline $\mathbf{0}$ & & Pretes & Posttes \\
\hline & & $t$ & $t$ \\
\hline 1 & $\begin{array}{c}\text { Eksperime } \\
\mathrm{n}\end{array}$ & 65,14 & 79,85 \\
\hline 2 & Kontrol & 66,07 & 71,71 \\
\hline
\end{tabular}

Tabel di atas menunjukkan hasil pretest dan posttest kedua kelompok penelitian terdapat perbedaan. Rata-rata nilai pretest kelompok eksperimen adalah 65,14 dan kelompok kontrol adalah sebesar 66,07. Sedangkan nilai rata-rata posttest kelompok eksperimen adalah 79,85 dan kelompok kontrol adalah sebesar 71,71. Hal tersebut menunjukkan bahwa sebelum diberikan perlakuan perolehan nilai pretest kelompok kontrol lebih tinggi dibandingkan perolehan nilai pretest kelompok eksperimen. Dan setelah diberikan perlakuan, ternyata perolehan nilai posttest kelompok eksperimen lebih tinggi dibandingkan perolehan nilai pretest kelompok kontrol.

Perbandingan nilai pretest dan posttest kelompok eksperimen dan kontrol dapat disajikan dalam bentuk grafik berikut.

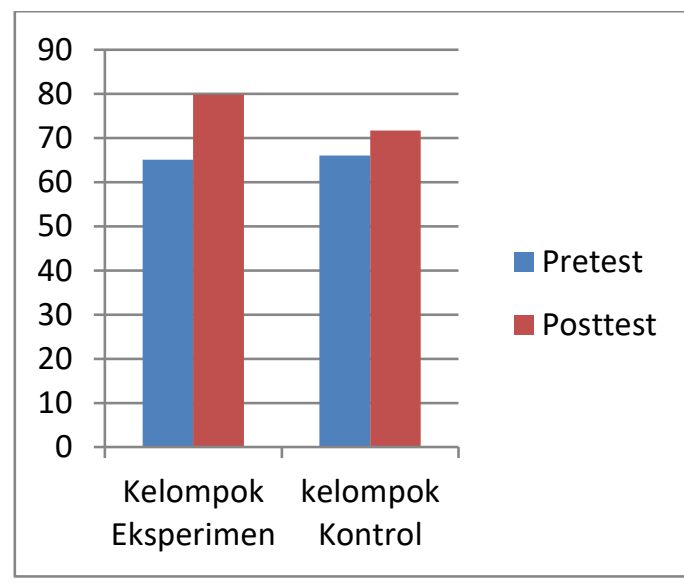

Gambar 4.5 Diagram Batang Perbandingan Nilai Pretest dan Posttest

Kelompok Eksperimen dan kontrol

Diagram diatas dapat dilihat bahwa terdapat perbedaan capaian hasil belajar dari kedua kelompok. Peningkatan hasil belajar dilihat dari nilai rata-rata pretestposttest kelompok eksperimen dari nilai 65,14 menjadi 79,85. Sedangkan peningkatan hasil belajar dilihat dari nilai rata-rata pretest-posttest pada kelompok kontrol dari nilai 66,07 menjadi 71,71. Hal ini menunjukkan bahwa perolehan nilai posttest kelompok eksperimen lebih tinggi daripada kelompok kontrol. Dan juga menunjukkan bahwa terdapat 
pengaruh penggunaan metode bermain peran terhadap hasil belajar siswa dalam pembelajaran PKn di kelas VB (kelompok eksperimen).

\section{B. Pengujian Prasyarat Analisis Data dan Pengujian Hipotesis}

\section{Uji Normalitas Pretest dan}

\section{Posttest}

Pada penelitian ini, peneliti menggunakan menggunakan uji liliefors dengan bantuan microsoft office excel dalam menghitung uji normalitas yang berfungsi untuk mengetahui apakah sebaran data berdistribusi normal atau tidak. Sampel dari penelitian berjumlah 28 orang, berdasarkan tabel L kritis maka Ltabel=0,173.

Tabel 4.8 Uji Normalitas Kelompok Eksperimen dan Kelompok Kontrol

\begin{tabular}{ccccc}
\hline $\mathbf{N}$ & \multicolumn{1}{c}{ Data } & L & L & Keterangan \\
o & hitung & tabel & Normal \\
1 & $\begin{array}{l}\text { Pretest } \\
\text { Kelompok }\end{array}$ & 0,1430 & 0,173 & \\
& $\begin{array}{l}\text { Kontrol } \\
\text { Pretest }\end{array}$ & & & Normal \\
& $\begin{array}{l}\text { Kelompok } \\
\text { Eksperimen }\end{array}$ & 0,1135 & 0,173 & \\
2 & & & Normal \\
& $\begin{array}{l}\text { Posttest } \\
\text { Kelompok }\end{array}$ & 0,1479 & 0,173 & \\
& $\begin{array}{l}\text { Eksperimen } \\
\text { Posttest } \\
\text { Kelompok }\end{array}$ & 0,1589 & 0,173 & Normal \\
& & & \\
\hline
\end{tabular}
Sumber : Data Sekunder(2018)

Hasil uji normalitas menyatakan bahwa data berdistribusi normal. Hal ini ditunjukkan dengan pretest kelompok kontrol $0,1430<0,173$, posttest kelompok kontrol $0,1589<0,173$. Pretest kelompok eksperimen 0,1135 < 0,173, dan posttest kelompok eksperimen $0,1479<0,173$. Pada penelitian didapat Ltabel $(0,173)$ lebih besar dari Lhitung, maka data pretest dan posttest dari kedua kelompok berdistribusi normal. Dengan hasil perhitungan yang menunjukkan kenormalan distribusi, maka data tersebut sudah memenuhi syarat untuk dianalisis.

\section{Uji Homogenitas}

Uji homogenitas dilaksanakan setelah uji normalitas. Tujuannya adalah mengetahui apakah data berasal dari populasi yang homogen atau tidak. Pada penelitian ini hasil dari uji homogenitas yang diperoleh dengan menggunakan uji-F dengan rumus :

$$
F=\frac{s_{1}{ }^{2}}{S_{2}{ }^{2}}
$$

Tabel Hasil Uji Homogenitas Kelompok Eksperimen dan Kelompok Kontrol

\begin{tabular}{lccc}
\hline Data & $\begin{array}{c}\text { F } \\
(\mathbf{m a x}) \\
\text { hitung }\end{array}$ & $\begin{array}{c}\text { F(max) } \\
\text { tabel }\end{array}$ & $\begin{array}{c}\text { Keterang } \\
\text { an }\end{array}$ \\
Pretest & 1,2595 & 4,02 & Homogen \\
& 5163 & & \\
Posttest & 2,1428 & 4,02 & Homogen \\
& 4719 & & \\
\hline
\end{tabular}


Dalam uji homogenitas kriteria pengujian terima $\mathrm{H}_{0}$ jika $\mathrm{F}$ (max) hitung $\leq \mathrm{F}(\max )$ tabel. Pada penelitian ini data pretest diperoleh nilai $1,25955163 \leq$ 4,02 yaitu $F(\max )$ hitung $\leq \mathrm{F}(\max )$ tabel maka $\mathrm{H}_{0}$ diterima sehingga disimpulkan bahwa populasi mempunyai variansi yang homogen. Sedangkan data posttest diperoleh nilai 2,14284719 $\leq$ 4,02 yaitu $F(\max )$ hitung $\leq F(\max )$ tabel maka $\mathrm{H}_{0}$ diterima sehingga disimpulkan bahwa populasi mempunyai variansi yang homogen.

\section{Pengujian hipotesis}

Pengujian hipotesis dilakukan uji normalitas dan uji homogenitas, diketahui bahwa kedua kelompok sampel memiliki data hasil belajar berdistribusi normal dan variansi yang homogen, pengambilan keputusan dan penarikan kesimpulan terhadap uji hipotesis dilakukan dengan uji t pada taraf signifikansi 5\% yang dianalisis dengan rumus t-test untuk menguji perbedaan rata-rata nilai postest dari kedua kelompok. Rumus t-tes yang digunakan sebagai berikut:

$$
\mathrm{t}=\frac{x_{1}-x_{2}}{\sqrt{\frac{s_{1}^{2}}{\mathrm{n}_{1}}+\frac{s_{2}^{2}}{\mathrm{n}_{2}}}}
$$

Berdasarkan hasil perhitungan menggunakan rumus tersebut diperoleh nilai $t_{\text {hitung }}$ adalah 3,2480 dan tabel adalah 2,00488. Dengan demikian dapat diketahui bahwa hasil posttest kelas eksperimen $t_{\text {hitung }}>t_{t a b e l}$, maka dapat disimpulkan bahwa Ha diterima, artinya ada pengaruh yang signifikan dalam penggunaan metode bermain peran terhadap hasil belajar PKn siswa kelas V SDN 17 Batu Gadang Agam tahun ajaran 2018/2019.

\section{PEMBAHASAN}

Penelitian ini diadakan untuk mengetahui pengaruh dalam penggunaan metode bermain peran terhadap hasil belajar PKn siswa kelas V SDN 17 Batu Gadang Agam tahun ajaran 2018/2019. Penelitian dilaksanakan pada bulan Agustus dan September dengan empat kali pertemuan, standar kompetensi, kompetensi dasar serta materi yang sama.

Tes dalam penelitian ini ada berupa tes awal (pretest) dan tes akhir (posttest). Sebelum tes diberikan kepada kelas sampel, tes diuji cobakan terlebih dahulu pada sekolah yang KKM dan Akreditasi sekolahnya sama dengan tempat penelitian. Peneliti menguji validitas instrumen soal, daya beda soal, taraf kesukaran, dan reliabilitas soal. Soal yang diuji cobakan berjumlah 40 butir soal. Setelah di uji validitas soal, daya beda, taraf kesukaran, dan reliabilitas soal yang yang layak di gunakan hanya berjumlah 13. Dalam penelitian ini soal yang dipakai untuk dijadikan soal pretest 
dan posttest yaitu 25 butir soal. oleh karena itu, untuk melengkapi 25 butir soal yang dipakai, maka 12 butir soal yang ditolak direvisi.

Dalam pelaksanaannya, terlebih dahulu diadakan pretest untuk mengetahui kondisi awal siswa setara atau tidak. Pada akhir penelitian atau setelah materi diajarkan diadakan posttest untuk mengetahui hasil belajar siswa.

Berdasarkan data yang diperoleh setelah penelitian dilaksanakan terdapat perbedaan hasil belajar kelompok eksperimen yang menggunakan metode bermain peran mendapatkan nilai ratarata posttest 79,85 dan kelompok kontrol yang mendapatkan perlakuan pembelajaran konvensional mendapatkan nilai rata-rata posttest 71,71 .

Berdasarkan analisis data dengan statistik parametrik, hasil belajar di uji menggunakan uji-t (independent sampel t-test), pada hasil perhitungan menunjukkan ada pengaruh yang signifikan antara kelompok eksperimen yang telah diajar dengan metode bermain peran dengan kelompok kontrol yang diajar dengan pembelajaran konvensional. Hal ini dapat dilihat pada hasil belajar siswa yang diberikan kepada kelompok eksperimen dan kelompok kontrol. Dengan menggunakan metode bermain peran pada kelompok eksperimen hasil belajar siswa jauh lebih tinggi dari sebelumnya. Sesuai dengan pendapat Sudjana (2009:22) menyatakan "Hasil belajar adalah kemampuan-kemampuan yang dimiliki siswa setelah ia menerima pengalaman belajarnya".

Metode bermain peran dapat membantu siswa dalam mendalami mata pelajaran, mengembangkan keterampilan, sikap dalam memecahkan maslah pada kehidupan sehari-hari. Dalam metode bermain peran ini siswa langsung terlibat dalam bermain peran, sehingga siswa tidak merasa jenuh atau bosan dalam mengikuti proses belajar mengajar. Hal ini berdampak positif terhadap hasil belajar siswa, sebab dalam metode bermain peran ini dapat memotivasi siswa untuk berkreativitas dan menjadikan siswa mandiri dalam mengekspresikan diri untuk suatu materi yang sedang dipelajari.

Secara umum terjadinya perbedaan hasil belajar siswa dikarena dalam metode bermain peran meningkatkan kreativitas belajar siswa, meningkatkan pemahaman siswa terhadap materi yang dipelajari, meningkatkan keberanian siswa sehingga dapat membangun motivasi belajar pada siswa dan pada akhirnya sangat berpengaruh terhadap hasil belajarnya. 


\section{SIMPULAN}

Berdasarkan hasil penelitian dan pembahasan, menunjukkan bahwa ada pengaruh yang signifikan dalam penggunaan metode bermain peran terhadap hasil belajar PKn siswa kelas V SDN 17 Batu Gadang Agam. Hal ini dibuktikan dari hasil uji-t (independent samsple t-test) dengan taraf signifikansi $5 \%$ diperoleh $\mathrm{t}_{\text {hitung }} 3,2480>\mathrm{t}_{\text {tabel }}$ 2,00488. Hasil belajar PKn yang diperoleh kelompok eksperimen lebih tinggi dari pada kelompok kontrol, ditunjukkan dari nilai rata-rata posttest yang diperoleh kelompok eksperimen sebesar 79,85 dan nilai rata-rata posttest yang diperoleh kelompok kontrol sebesar 71,71.

Dengan demikian dapat diketahui bahwa hasil posttest kelas eksperimen $t_{\text {hitung }}>t_{\text {tabel }}$, maka dapat disimpulkan bahwa Ha diterima, artinya ada pengaruh yang signifikan dalam penggunaan metode bermain peran terhadap hasil belajar siswa dalam pembelajaran PKn di kelas V SDN 17 Batu Gadang Agam tahun ajaran 2018/2019.

\section{DAFTAR RUJUKAN}

B.Uno, Hamzah \& Satria
Koni.2012.Assessment Pembelajaran.Jakarta:Bumi Aksara. Hamdayama,Jumanta.2014.Model dan Metode Pembelajaran Kreatif dan Berkarakter.Bogor:Ghalia Indonesia. Reinita.2012.Penerapan Pembelajaran Keterampilan Pemecahan Masalah Sosial untuk Meningkatkan Kualitas Pembelajaran PKn di SD Kecamatan Lembah Segar Kota Sawahlunto (http://ejournal.unp.ac.id pdf di akses 06 Februari 2018)

Sugiono.2012.Metode Penelitian Pendidikan.Bandung:Alfabeta.

Suharsimi, Arikunto.2006. Prosedur Penelitian Suatu Pendekatan Praktik.Jakarta: PT Rineka Cipta 